\title{
Triple Helix: a sustainable economy for hijab SMEs in the new normal
}

\author{
Jun Surjanti $i^{*}$, Tony Seno Aji ${ }^{2}$, Sanaji ${ }^{3}$, Setya Chendra ${ }^{4}$ \\ ${ }^{1,2,3}$ Faculty of Economics, Universitas Negeri Surabaya, Surabaya, Indonesia \\ ${ }^{4}$ Faculty of Engineering, Universitas Negeri Surabaya, Surabaya, Indonesia \\ *Corresponding author: junsurjanti@unesa.ac.id
}

\begin{abstract}
Although the COVID-19 pandemic has gradually improved, people's activities have not recovered to normal due to various conditions. This period is a transition period known as the "New Normal". Besides its impact on people's health, COVID-19 also affects other aspects, including the economy, education, and law. The economic impact highly touches low-medium class people including SMEs as the business activities which need to be halted due to PSBB (Large-Scale Social Restriction). Triple Helix is a SMEs' development model that links Science (S), Government (G), and Business (B). This article aims to examine whether Triple Helix with SGB Balanced model is possibly utilized to revive the Hijab SMEs business activity. This study is descriptive-qualitative research and analyzed using the Miles and Hubberman techniques. Data were obtained through online questionnaires and interviews from hijab craftsmen associating with two SMEs. The results show that respondents have successfully adapted to the New Normal and resumed their business activity by implementing technology and information given by the $\mathrm{S}$ (science) agent and the $\mathrm{G}$ (government) agent's assistance. Therefore, it indicates that implementing Triple Helix provably revives the Hijab SMEs business activities.
\end{abstract}

Keywords: Triple Helix, Hijab SMEs, Production, New Normal

\begin{tabular}{ll}
\hline JEL Classification Code: F64, M11, L26 DOI: 10.20885/jsb.vol25.iss1.art3 & D26
\end{tabular}

\section{Introduction}

As of 3 October 2020, more than 34.4 million the 2019 Corona Virus Disease (COVID-19) cases had been reported in 188 countries and territories with more than 1.02 million deaths; more than 23.9 million people have recovered ${ }^{1}$. Meanwhile in Indonesia, data obtained (up to) October 2, 2020, have reported 295,499 cases (WHO, 2020). This number puts Indonesia into the second highest country in Southeast Asia, after the Philippines and in terms of mortality rates, Indonesia ranks third in Asia and 17th in the world (Allard \& Lamb, 2020). This situation has shocked many people around the world; this has resulted in many studies that have discussed various related issues (Aji, Berakon, \& Husin, 2020). Various policies such as social and physical distancing have significant impacts on socio-economic, finance, and demands supply (Aji, Berakon, \& Husin, 2020). This serious impact is due to the cessation of business activities. In beginning of the pandemic (February to April), Indonesia had implemented PSBB (Large-Scale Social Restriction) which aimed to limit physical contact among people in accordance with Government Regulation Number 21 of 2020 on regulating large-scale social restrictions as a response to COVID-19 (Marpaung, et.al, 2020). Hereinafter, various business establishments, such as shopping centers, wholesale markets, and other businesses were closed to prevent the virus transmission. From the health perspective, this policy was indeed very appropriate as the prevention action (Betsch, 2020). Yet, this policy created equally worrying impacts, especially on economy evidenced by a survey conducted by LIPI on May 3-12, 2020. The survey reported that nearly half of respondents (44\%) lost most of their income and $17 \%$ lost their jobs because PSBB limits their work activities (The Conversation. 2020). To understand the effects of this pandemic to economic turmoil, Nicola et al (2020) generalize it into three parts, namely the primary sector including industries involved in raw material extraction, secondary sectors involved in the production of finished products, and tertiary sectors to include all service-providing industries. 
Accordingly, government and many economists suggest that people should strike hard in order to leave the situation. Thus, various attempts conducted regardless the outcomes. These attempts creates new phenomenon which known as "New Normal". According to Rahayu Surtiati Hidayat, a linguist from the University of Indonesia, the word "new normal" is a noun that describes a new normal condition (detiknews. 30 May 2020). Meanwhile, according to Joko Widodo, President of the Republic of Indonesia, "New Normal" is a term that describes a scenario or steps to accelerate the handling of COVID-19 in the health, social and economic sectors (Marpaung, 2020). Therefore, new normal can be defined as a transitional period in which policies and regulations regarding the handling of COVID-19 in the health, social and economic sectors are enforced in the community (Habibi, 2020). Although the new normal period allows economic activity (SMEs) to resume, proved by the re-opening of shopping centers and wholesale markets, the business activities (carried out by SMEs) are relatively low. These are generally influenced by the declining level of the Indonesian economy. Corresponding to this condition, Indonesian government established policies that mainly focussed on two main aspects, namely economy and health. Erikson (n.d) states that during COVID-19, the economic growth has strongly related to the public health; thus, government should be able to bridge both factors (economy and health) in order to decrease the tensions. Supported by Linder et al. (2020), the collaboration of health and economic aspects can increase the public welfare as well as maintain social ecosystems. According to Sri Mulyani, the Ministry of Finance of the Republic of Indonesia, the decline in economic growth was caused by (almost) all components of GDP decline which majorly impact on the micro economy, including: employment termination (an increase in the unemployment rate) and a decrease in people's purchasing power. She stated that there is a probability that Indonesia will face the worst economic scenario by the end of 2020 where the economic downturn is ranged from $-1.7 \%$ to $-0.6 \%$ (Bareksa, 24 Sep 2020). However, Mulyani agree that there is a possibility that the condition improves in the last three months of 2020 after the new normal is publicly carried out (Kompas.com - 31/08/2020).

One of the small and medium economic actors who have been greatly affected by this pandemic is SMEs. SMEs are one of the main economic drivers in developing countries that encourage economic growth because they can create new jobs, expand the tax, and drive innovation (Katua, 2014). Surjanti, et.al (2018) found that Gresik hijab SMEs absorb labor and affect the local economy. In the prior research, Surjanti et al. (2019) found that the Gresik hijab SMEs was able to face the 1998 monetary crisis by employing locals and ensuring the stability of local economy. However, during the COVID-19 pandemic, Gresik hijab SMEs were suddenly hit by the situation threatening their their existence. This threat is mainly caused by the market closure due to large-scale social restriction. Market (local and national) are closed resulting in the discontinuation of their business activity.

Dealing with both economic and health conditions, government has established policies and regulation focussing on strengthening businesses in SMEs (jawapos.com, 16 April 2020). It is cause by SMEs are regarded as one of significant actors to ensure the national economic stability. One of the policy proposed by the Indonesian government is to domestically produce non-medical PPE (Personal Protective Equipment), such as mask and accordingly, the fashion/garment SMEs highly relate to this issue (liputan6.com, 6 April 2020). Responding to this situation, researchers view this as an opportunity and potential that can encourage the SMEs after facing the death-end in the beginning of the pandemic.

Triple Helix (TH) is a synergy of science, business and government. Science serve as sources of information, knowledge, and technology; business serves as the wheel of economy which ensures the economic stability (micro and macro); while government serves as policy makers and controller who guarantee and maintain the stability through policy and regulation (Etzkowitz \& Leydesdorff, 2000). TH is a model often used to develop SMEs because it carries a Science-Government-Business approach in developing the SMEs skilss and ability in conducting business activities. Implementing TH in this study is based on Surjanti et al. (2018) Triple Helix Balanced SGB model with three agents, namely: Science (S), Government (G), and Business (B). This model selected is because TH Balanced SGB model considered as appropriate method to overcome problems arising in hijab SMEs who are affected by the pandemic. 
Liu \& Huang (2018) mention that university is an institution with ability differentiate sources and skills, so it is feasible to serve as a science agent in TH. Fitriani, Wahjusaputri, \& Diponegoro (2019) define Triple Helix as a knowldge-based economic model; hence, it connects aspects of knowledge to assist the business development on SMEs. While, Li, Arora, Youtie, \& Shapira (2016) illustrate the bigger scope of Triple Helix from industry, government, and collaboration of universities in order to encourage innovation and economic development at both micro and macro. Furthermore, Jowkar et al. (2020) state that to achieve sustainable development, every country needs distinct interactions of universities, government and industry. In contrary, Dankbaar (2019) mention that TH is not always successfull; some failures in Triple Helix are commonly due to the imbalance roles of the agents. This is supported by Oplakanskaia, Osmuk, \& Pomorina (2019) who found there is a prohibition to implement TH model by the Russian government because of lack understanding of each agent in performing its roles.

This study aims to determine whether implementing Triple Helix can revive hijab SME business activities during New Normal as a means of supports to micro and macroeconomic development in Java, and particularly in Gresik.

\section{Literature Review}

\section{New Normal}

According to Buheji and Ahmed (2020), new normal is a situation where people begin to change their lifestyle adapting with the pandemic. They argue that the new normal makes society adopt to the changing circumstances. Muhyiddin (2020) defines new normal as a term to describe the condition in which adapting to the pandemic situation where the activities should be adjusted to health protocols.

According to Wiku (Indonesian COVID-19 management team chief), new normal is a period when people must change prior habit according to standard set by the government in order to prevent COVID-19 transmission. Meanwhile, WHO states that in the new normal, people cannot simply adapt to the changes but they should also enforce them in certaim standard in order to stop the COVID-19 transmission (Buheji, 2020). Moreover, Habibi (2020) define new normal as a condition which is different with the previous standard of normal and affects all aspects of people's lives. Supporting government on COVID-19 prevention policy, the Ministry of Manpower of the Republic of Indonesia through its Letter No. M/7/AS.02.02/V/2020 on business sustainability in the new normal states that all business activities (especially for re-opened businesses) must meet all requirement according to COVID-19 preventation standard prior the re-opening (Marpaung, et.al, 2020). Likewise, to cope-up with the condition of new normal, Gresik hijab SMEs prepare themselves employing certain business stategies to ensure the continuity of business activity, including by preparing new design according to PPE standard and following government policy in term of both physical and social distancing.

\section{Triple Helix Model}

The triple helix is a strategic model relating to three agents, respectively University (Science), Industry (Business), and the Government to develop a business (Ivanova \& Leydesdorff, 2014). Meanwhile, Amaral et al. (2017) state that Triple Helix (known as TH) has reciprocal relationship among universities, business, and government and those three are related in quantity, quality, and complexity to create a hybrid organization. Surjanti (2018) argues that to determine the innovation factors, Triple Helix is appropriate for designing development strategies and improving product or industrial quality. Triple Helix with the concept of university-business-government relations is an alternative model to explain the economic development system in terms of its social context (Etzkowitz \& Leydesdorff, 2000).

Other researches find that Triple Helix refers to the synergy of different factors to achieve knowledge-based economic and social development (Cai, 2014). Accordingly, TH model has the potential to develop the people's economy by prioritizing the roles of universities, private sector, and government to produce new institutional and social forms for production, transfer, and application of knowledge (Gachie, 2020). In addition, Jaelani (2019) stated that the Triple Helix prioritizes the role 
of knowledge (university), social (community) in developing the economy (business). This study analyzes TH Balanced SGB model where State University of Surabaya - Unesa as S agent, some of Gresik government institutions as G agent, and hijab SMEs and hijab craftsmen as B agent.

\section{SME Performance}

Jevwegaga et al (2018) mention that in Negeria, SMEs performances are closely related to science and education on entrepreneurship obtained by the business actors. The managerial skill and production have significant roles on SMEs development. Moreover, both aspects highly relate to knowledge, information, technology (Houssein \& Elaswad, 2013).

According to Sitharam \& Hoque (2016), business environment is defined as factors both inside and outside of the organization affecting the continuity and success of the organization and play an important role in the growth of SMEs. Tambunan (2008; 2009) mentions that SMEs in Indonesia are micro-businesses with five characteristics, namely intensifying labors, prioritizing the middle-lower class of society, close-related to society, personal capital, and producing consumable goods.

While in order to measure SMEs performances, customers' satisfaction can be employed (Yang, 2003). Yang mentions that customers' satisfaction serve as data to develop and improve business through sustainable actions in order to increase business profit. Büschken, Otter, \& Allenby (2013), in addition, say that customers' satisfaction induces global satisfaction through the product evaluation of different attributes. While He, Hoyle, \& Chen (2011) find that customer satisfaction index can be used to measure the customer acceptability in certain design. Thus, this study aims to determine whether TH Balanced SGB model is feasible to revive hijab SMEs business activities in Gresik after stopped due to pandemic. In addition this study defines the additional roles of S in TH Balanced SGB model.

\section{Research Methods}

This study is qualitative-descriptive research using Miles and Hubberman technique to analyze the data. Data were divided into two, hijab craftsmen income and customer responses. Data were collected using online questionnaires and interviews from 55 hijab craftsmen who assosiate with two SMEs (Fahmi and Izza Collection) located in Gresik. In addition 150 hijab mask users were given online questionnaires in oder to depict their response. Open Discussion of all TH agents (S, G, and B) were conducted to determine roles of each agents prior to analyze the roles incissions emerged. Analyzed data were later process in order to determine the synergical relationship of TH agents. The result was then examined TH Balanced SGB significant roles in reviving the business activity after COVID-19 lockdown (new normal).

Table 1. Average Incomes of Hijab Craftsmen in the New Normal

\begin{tabular}{|c|c|c|c|c|c|c|}
\hline \multirow{3}{*}{$\begin{array}{c}\text { Sources of Income } \\
\text { (each production activity) }\end{array}$} & \multicolumn{6}{|c|}{ Average incomes } \\
\hline & \multicolumn{2}{|c|}{$\begin{array}{c}\text { Beginning of } \\
\text { Pandemic (IDR) }\end{array}$} & \multicolumn{2}{|c|}{$\begin{array}{c}\text { After TH } \\
\text { Implementation (IDR) }\end{array}$} & \multicolumn{2}{|c|}{$\begin{array}{c}\text { Difference } \\
\text { (IDR) }\end{array}$} \\
\hline & Fahmi & Izza & Fahmi & Izza & Fahmi & Izza \\
\hline Cloth cutting & 0 & 0 & 4,000 & 2,500 & 4,000 & 2,500 \\
\hline Cutting hijab inner & 0 & 0 & 1,000 & 2,500 & 1,000 & 2,500 \\
\hline Sewing & 0 & 0 & 15,000 & 22,500 & 15,000 & 22,500 \\
\hline Embroidering & 0 & 0 & 42,000 & 52,500 & 42,000 & 52,500 \\
\hline Coarse finishing & 0 & 0 & 2,400 & 3,000 & 2,400 & 3,000 \\
\hline Fine finishing & 0 & 0 & & 3,000 & & 3,000 \\
\hline Total & 0 & 0 & 64,400 & 86,000 & 64,400 & 86,000 \\
\hline SMEs Net Profit & 0 & 0 & $1,575,000$ & $1,575,000$ & $1,575,000$ & $1,575,000$ \\
\hline
\end{tabular}

Source: data analysis

*During pandemic, the SMEs experienced deficit income due to market close (lockdown) 


\section{Results and Discussion}

\section{Result}

The results show that implementing Triple Helix (TH) Balanced SGB model to revive hijab SMEs' business activities is proved to be feasible. It shows by how hijab SMEs successfully overcome their economic crises (zero income) caused by COVID-19 (pandemic) and drive the micro-economic sustainability in Gresik (particularly the regions where Gresik hijab SMEs are located). New $\mathrm{TH}$ Balanced SGB model implementation creates additional roles in all $\mathrm{TH}$ agents whether in form of assistance, support, and coordination. Funding and Marketing, which previously belong to G and B, become additional roles of $\mathrm{S}$, while consultation (information and knowledge), which previously belong to $\mathrm{S}$, now is known as the additional role of $\mathrm{G}$. B, which was previously solely focus on conducting business, now has additional function to serve as sources of data for both $\mathrm{S}$ and $\mathrm{G}$. Moreover, B in from of SMEs has another roles as consultant for the SMEs actors (hijab craftsment) in term of providing knowledge and capital. Meanwhile, S and $\mathrm{G}$ collaborate to create the best methods to drive the business activities on B. Furthermore, although the new TH Balanced SGB model creates diffusion on the roles of each agents, all agents adopt to synergically creating balance relationship. Adopting to TH Balanced SGB model designed by Surjanti et al. (2018), this study finds the relationship of each agent (Triple Helix agents) on business activities of Gresik hijab SMEs during the pandemic (see Table 2).

Table 2. The Role of Triple Helix Agent in Hijab SMEs Gresik

\begin{tabular}{|c|c|c|c|c|}
\hline Agent & & Description & Note & $\begin{array}{l}\text { Role of TH Agent } \\
\text { (See Figure 1) }\end{array}$ \\
\hline S (Science) & S1 & Assisting SMEs in business & Assistance & 2,3 \\
\hline \multirow{4}{*}{$\begin{array}{c}\text { By State } \\
\text { University of } \\
\text { Surabaya }\end{array}$} & S2 & $\begin{array}{l}\text { Providing knowledge, equipment, and appropriate } \\
\text { production technique }\end{array}$ & Support & 2,3 \\
\hline & S3 & $\begin{array}{l}\text { Becoming center of knowledge and technology } \\
\text { development for SMEs }\end{array}$ & Support & 3 \\
\hline & $\mathrm{S} 4 *$ & Funding & Support & 4 \\
\hline & S5* & Marketing & Support & $1,2,3$ \\
\hline $\begin{array}{l}\text { G (Government) } \\
\text { By Department of }\end{array}$ & G1 & $\begin{array}{l}\text { Assisting SMEs to solve issues in production, sales, } \\
\text { legality and laws }\end{array}$ & Assistance & 1,2 \\
\hline $\begin{array}{l}\text { Industry, Tradem } \\
\text { \& Cooperation }\end{array}$ & G2 & $\begin{array}{l}\text { Providing equipment and appropriate technique for } \\
\text { SMEs }\end{array}$ & Assistance \& Support & 1,2 \\
\hline \multirow[t]{2}{*}{ Gresik } & G3* & Funding & Cooperation & 4 \\
\hline & G4* & Consultant & Support & 1,2 \\
\hline \multirow[t]{6}{*}{$\begin{array}{c}\text { B (Business) } \\
\text { By Hijab SMES }\end{array}$} & B1 & $\begin{array}{l}\text { Providing information for the business potential to } \\
\text { develop (for } \mathrm{S} \text { and } \mathrm{G} \text { ) }\end{array}$ & Assistance & $1,2,3$ \\
\hline & B2 & $\begin{array}{l}\text { Becoming object of study and research to develop and } \\
\text { implement new technology and government policy }\end{array}$ & Support & $1,2,3$ \\
\hline & B3 & Becoming business actor (assisted by $\mathrm{S}$ and $\mathrm{G}$ actor) & Assistance \& Support & 1,3 \\
\hline & B4* & $\begin{array}{l}\text { Develop embriyo cooperation in sentra Hijab (assisted by } \\
\mathrm{S} \text { and } \mathrm{G} \text { ) }\end{array}$ & Cooperation & 4 \\
\hline & $\mathrm{B} 5 *$ & Consultant & Support & 1,3 \\
\hline & B6* & $\begin{array}{l}\text { Improve work ethic \& culture (from owner to co- } \\
\text { worker) (assisted by Unesa/S) }\end{array}$ & Cooperation & 3 \\
\hline
\end{tabular}

Source: data analysis

* Additional roles of each actors during pandemic (including in the new normal)

\section{Discussion}

From the interviews, the results of the analysis find that there was a cessation of business activities in SMEs (see Table 1) seen from the 0 (zero) income earned by respondents received. In addition, both hijab SMEs (respondents) also suffered losses due to the products accumulation (from previous production) which occurred because market closed during the PSBB (large-scale social restriction). 
The report finds that almost $95 \%$ of the products were unsold in which resulted by the decline of local economy. Responding to these conditions, researchers are proposed Triple Helix (TH) Balanced SGB model as an approach to deal with the pandemic for Gresik hijab SMEs.

In this study, implementing Triple Helix focused on the production process. Science (represented by State Univeristy of Surabaya/Unesa) introduces the concept of adaptation to ongoing conditions or issues by optimizing the use of technology and information to SMEs actors. Unesa as agent of science taught or introduced the hijab mask designs with PPE (personal protective equipment) standards responding to market demands in pandemic COVID-19 (see Table 2).

This study is an experimental study of implementing TH Balanced SGB model to revive Gresik hijab SMEs. The experiment was conducted by adjusting TH Balanced SGB model to deal with hijab SMEs problem during the pandemic. It is by adding roles in each $\mathrm{TH}$ agent to corespond the situation. $\mathrm{S}$ agent in TH Balanced SGB model perform additional roles in term of funding and marketing. S, that previously serves as agent of knowledge and information for the hijab SMEs, has other functions that are provide funding which originally is the role of $\mathrm{G}$ and assist in marketing which proviously carried out by $\mathrm{B}$. While providing information and knowledge (previously belong to $\mathrm{S}$ ) become additional role of $\mathrm{G}$ and $\mathrm{B}$. The depiction of this role in B is when B (in term of SMEs) provides knowledge, information, and funding to SMEs actors (hijab craftsmen). Moreover, the collaboration between $\mathrm{S}$ and $\mathrm{G}$ forms a new role as a companion and developer of cooperative ideas (for agent $\mathrm{B}$ ). This function makes $\mathrm{S}$ and $\mathrm{G}$ as supporters to change and improve agent B's work ethic and performance.

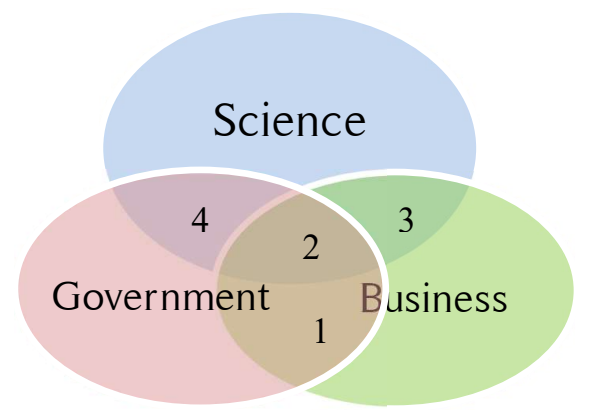
Note:
S: Science
G: Government
B: Business
1: Relationship between government \& business (support)
2: Involvement of all agents $(S, G, B)$
3: Relationship between business \& science (Assistance)
4: Relationship between government \& science (cooperation)

Figure 1. The Relationship of TH Agents

The result explains that the relationship of the agents (S-G-B) (See Fig. 1) during the pandemic period (especially in the New Normal) is synergically created. The incision of agents indicates that their roles intersect to each other and create a synergy relatuionship. \#1 and \#3 (in Fig. 1) show the incision of $S$ and $G$ to $B$ meaning that both ( $S$ and $G$ ) have a role to assist $B$ and vice versa. $S$ and $G$ roles to $\mathrm{B}$ is mainly as assistances and supports to drive $\mathrm{B}$ in conducting their business activity. While $\mathrm{B}$ mainly cooperates with both $\mathrm{S}$ and $\mathrm{G}$ in form of becoming data sources (for research to $\mathrm{S}$ and for policy considerations to $\mathrm{G}$ ). Meanwhile \# 4 shows the incision of $\mathrm{S}$ and $\mathrm{G}$ meaning that there is an additional role of $\mathrm{S}$ and $\mathrm{G}$ which previously only existed on each. However, this condition (phenomenon) is occured when TH Balanced SGB implemented during the pandemic. This chance is possibly occured due to the unusual causes where each agent has to extend their roles to cover-up the deficiencies occured because of the problem (pandemic).

Meanwhile, the government (G agent) assists hijab SMEs (B agent) to perform their busines activities by mentoring them (especially related to policies and capital -in form of funding-). By this assistance, the Gresik hijab craftsmen associated in two SMEs gain supports and driving force to resume or revive their business activities. This assistance becomes an insurance for B agent to assuredly carry out business activities. Of the overall situation, it is indicated that the relationship of $\mathrm{S}$ agent (university -UNESA-), G (government), and B (business actors - hijab craftsmen/SMEs-) represent the relationship in Triple Helix model. 
Data from respondents' income and SMEs performance (seen from consumers' satisfactions) are used to illustrate the TH Balanced SGB implementation in hijab SMEs Gresik. The use of SMEs performance in this case is in line with Yang (2003) who agree that TH success can be measured through consumers' satisfaction. Similarly, He, Hoyle, \& Chen (2011) argue that survey's on customers' satisfaction is used to guide the technical design to improve their production. This signifies that consumer's response on product can direct the business (Büschken, Otter, \& Allenby, 2013). Of prior studies, therefore, this study succesfully measured TH Balanced SGB implementation using consumer's response and level of demands as references. The analysis finds that consumers are satisfied with the new hijab mask which is product developed after hijab craftsmen (hijab SMEs) implemented TH Balanced SGB (see Fig. 2).

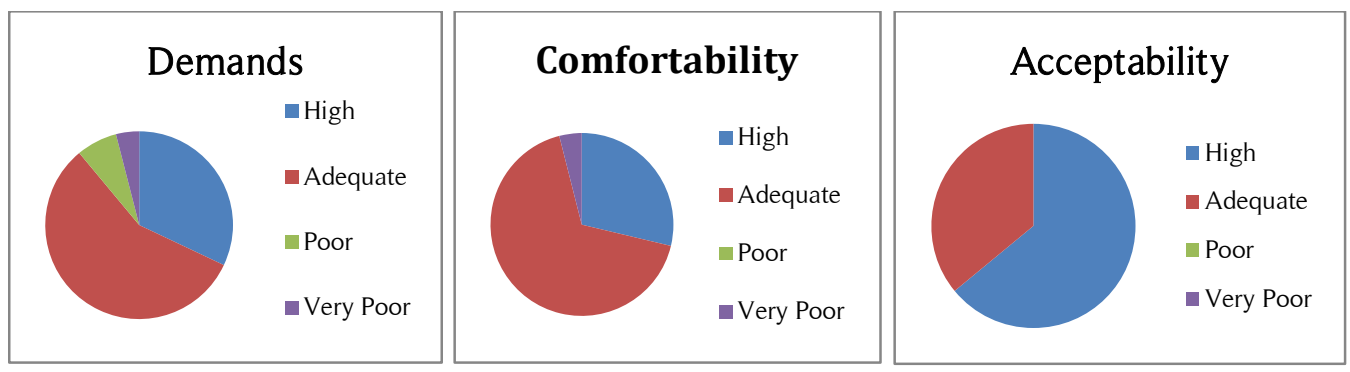

Figure 2. Market Response on Hijab Mask

Referring to market demands and market acceptability, it shows that the consumers' response on hijab mask made by the Gresik hijab SME were good (see Fig. 2). It is indicated from the diagram 3 (acceptability) that no consumer shows objections (poor and very poor responses) (see Fig. 2.3). It means that the business potential emerges from the new products. Thus, SMEs can be encouraged to resume their business activities. The high acceptance of consumers is due to the products' comfortability and it is obtained after SMEs successfully implemented technology/information (especially related to hijab designs) provided by science agent (Unesa). This indicates that the implementing science and technology (design) tailored to market demands (hijab masks according to PPE standard) has proved capably assisting the hijab SMEs production to resume their business activities. Using this design (hijab mask), hijab SMEs Gresik (B agent) can revive their activity and local economy (especially in the hijab craftsmen regions) proved by the income earned (See Table 2).

\section{Conclusion}

From the analysis, it can be concluded that implementing Triple Helix (TH) Balanced SGB model in the hijab SMEs Gresik during New Normal is provably able to revive the business activities that were halted due to the COVID-19. In addition, through the implementation, TH Balanced SGB evolves into new TH Balanced SGB model. This new model emerges due to the role diffusion of agents meaning that each agent has creates new roles which previously belongs to others. The roles diffusion (sciencegovernment-business) occuring in the $\mathrm{S}$ agent is not only as assistant who provides information but also as a support (in term of funding) who previously belong to $\mathrm{G}$ agent, while $\mathrm{G}$ agent has additional roles such as by providing knowledge and training that previously belong to $\mathrm{S}$ agent. Meanwhile, $\mathrm{B}$ agent is not only cooperating but it is also assisting $\mathrm{S}$ and $\mathrm{G}$ agents as sources of information in order to facilitate both agents with data used for researches. In addition, B (SMEs actors) has other roles extending the roles of $\mathrm{S}$ and $\mathrm{G}$ to the craftsmen who associate with SMEs. Finally, new TH Balanced SGB model is provably successfull to revice hijab SMEs business activity after forcefully stopped by the pandemic meaning that new TH Balanced SGB model is feasible as a method to drive business activity during the pandemic. 
Through this study, TH with Balanced SGB model is provably possible to be implemented to other SMEs. Hence, it indirectly will assist the micro economy. By then, it can reduce the national economic decline impacting on national stability. Moreover, this study can be used as a reference for further researches. Furthermore, in the future research, it is suggested to employ TH Balanced SGB especially in developing marketing strategy on hijab SMEs.

\section{References}

Aji, H. M., Berakon, I., \& Husin, M. M.. (2020). COVID-19 and e-wallet usage intention: A multigroup analysis between Indonesia and Malaysia, Cogent Business \& Management, 7(1), 1-16. DOI: $10.1080 / 23311975.2020 .1804181$

Allard, T. \& Lamb, K. (2020, April 28). Exclusive: More than 2,200 Indonesians have died with coronavirus symptoms, data shows. Reuters. https:// www.reuters.com/article/us-healthcoronavirus-indonesia-casualti-idUSKCN22A04N

Andora, H. (2020, April 16). Kebijakan Anggaran di Era Covid-19, Opini. Padek Jawapos. https://padek.jawapos.com/opini/16/04/2020/kebijakan-anggaran-di-era-covid-19/.

Betsch, C. (2020). How behavioural science data helps mitigate the COVID-19 crisis. Nature Human Behaviour, 41562. DOI: 10.1038/s41562-020-0866-1

Buheji, M. (2020). The New Normal-A New Era Full of Inspiration and Resilience after COVID-19. International Journal of Inspiration \& Resilience Economy, 4(2). DOI: 10.5923/j.ijire. 20200402.00 .

Buheji, M. \& Dunya A. (2020). Planning for 'The New Normal' - Foresight and Management of the Possibilities of Socio-economic Spillovers due to COVID-19 Pandemic. Business Management and Strategy, 11(1), 160-179.

Camillo, A. A. (2015). Strategic Management and Crisis Communication Interdependence in the Global Context: A Preliminary Investigation. Emerging Economy Studies, 1(1), 37-49. https://doi.org/10.1177/2394901514562302

Büschken, J., Otter, T., \& Allenby, G. M. (2013). The Dimensionality of Customer Satisfaction Survey Responses and Implications for Driver Analysis. Marketing Science, 32(4), 533-553.

Cai, Y. (2014). Implementing the Triple Helix model in a non-Western context: An institutional logics perspective. Triple Helix, 1(1), 1-20. DOI: 10.1186/s40604-014-0001-2.

Dankbaar, B. (2019). Design Rules for "Triple Helix" Organizations Design Rules for "Triple Helix" Organizations. Technology Innovation Management Review, 9(11), 53-61.

El Zowalaty, M. E., \& Järhult, J. D. (2020). From SARS to COVID-19: A previously unknown SARSrelated coronavirus (SARS-CoV-2) of pandemic potential infecting humans - Call for a One Health approach. One Health, 9(February), 100124.

https://doi.org/10.1016/j.onehlt.2020.100124

Erikson, S. (2020). Pandemics show us what government is for. Nature Human Behaviour, 4(5), 441442. DOI: 10.1038/s41562-020-0871-4

Etzkowitz, H. \& Leydesdorff, L. (2000). The Dynamics of Innovation: From National Systems and "Mode 2" to a Triple Helix of University-Industry-Government Relations. Research Policy, 29(2), 109-123. DOI: 10.1016/S0048-7333(99)00055-4.

Fitriani, S., Wahjusaputri, S., \& Diponegoro, A. (2019). Success Factors in Triple Helix Coordination: Small-Medium Sized Enterprises Success Factors in Triple Helix Coordination: Small-Medium 
Triple Helix: a sustainable economy for hijab SMEs in the new normal

Sized Enterprises in Western Java. ETIKONOMI, 18(2), 233-248. DOI: 10.15408/etk.v18i2.11548

Habibi, A., (2020). Normal Baru Pasca Covid-19. ADALAH Buletin Hukum \& Keadilan, 4(1), 197204. DOI: 10.15408/adalah.v4i1.15809

He, L., Hoyle, C., \& Chen, W. (2011). Examination of customer satisfaction surveys in choice modelling to support engineering design. Journal of Engineering Design, 22(10), 669-687.

Houssein, M.A, \& Elaswad, S.M.I (2013). Determinants of Manufacturing SMEs Growth: A Review. Journal of Manufacturing Operations Research and Sustainability, 1(2). Pp 46-59.

Ivanova, I. A., \& Leydesdorff, L. (2014). Rotational symmetry and the transformation of innovation systems in a Triple Helix of university-industry-government relations. Technological Forecasting and Social Change, 86, 143-156. DOI: 10.1016/j.techfore. 2013.08.022.

Jaelani, Aan. (2019). Triple Helix sebagai Model bagi Inovasi Pendidikan Tinggi: Analisis Logika Kelembagaan dalam Pengembangan Kewirausahaan dan Ekonomi. Al-Amwal: Jurnal Ekonomi dan Perbankan Syari'ah, 11(1), 121-138. DOI: 10.24235/amwal.v11i1.4544.

Jatim.suara.com. 7 April 2020. Korban Dampak Corona Mulai Terasa, Di Gresik 73 Buruh Kena PHK. https://jatim.suara.com/read/2020/04/07/005000/korban-dampak-corona-mulai-terasa-digresik-73-buruh-kena-phk. Accessed on 12 April 2020.

Jowkar, T., \& Vara, N. (2020). The Triple Helix of University, Government and Industry in the Field of Veterinary Science in Iran: Comparison of ISC and WOS publications. International Journal of Information Science and Management, 18(1), 73-91.

Jevwegaga, H., Ade-adeniji, O., Ibidunni, A. S., \& Olokundun, A. M., Borishade, T. T., Falola, H. O., Obaoye, D., \& Ogunniyi, A. (2018). Role of SMEs' Entrepreneurial Activities and Industrial Clustering on SMEs' Performance. Academy of Entrepreneurship Journal. 24(1), 1-7.

katadata.co.id. 21 April 2017. Sektor Apa yang Paling Banyak Serap Pekerja Wanita?, Data Stories, https://databoks.katadata.co.id/datapublish/2017/04/21/sektor-apa-yang-paling-banyakserap-pekerja-wanita. Accessed on 12 April 2020.

Kemenkes.go.id. 5 April 2020. Total 164 Pasien Covid-19 Sembuh, Jubir Pemerintah Minta Masyarakat Pakai Masker. https://www.kemkes.go.id/article/view/20040500002/total-164pasien-covid-19-sembuh-jubir-pemerintah-minta-masyarakat-pakai-masker.html. Accessed on 12 April 2020.

Kompas.com. 14 April 2020. Akademisi UGM: Efektivitas Masker Kain Rendah, Solusinya..., Edukasi, https://www.kompas.com/edu/read/2020/04/14/143714571/akademisi-ugmefektivitas masker-kain-rendah-solusinya?page=all. Accessed on 16 April 2020

Kompas.com. 2 April 2020. Bisa Dipraktikkan, Masker Kain Homemade Rekomendasi ITB, Trend, https://www.kompas.com/tren/read/2020/04/02/080400665/bisa-dipraktikkan-masker-kainhomemade-rekomendasi-itb-?page=all, diakses tanggal

Katua, N. T. (2014). The Role of SMEs in Employment Creation and Economic Growth in Selected Countries. International Journal of Education and Research, 2(2), 461-472.

Li, Y., Arora, S., Youtie, J., \& Shapira, P. (2016). Using web mining to explore Triple Helix influences on growth in small and mid-size firms. Technovation, 76(3), 3-14.

Linder, D., Cardamone, C., Cash, S. B., Castellot, J., Kochevar, D., Dhadwal, S., \& Patterson, E. (2020). Development, Implementation, and Evaluation of A Novel Multidisciplinary One Health Course for University Undergraduates. One Health, $9(11), 100121$. DOI: 10.1016/j. onehlt.2019.100121 
Liu, Y., \& Huang, Q. (2018). University capability as a micro-foundation for the Triple Helix model : The case of China. Technovation, 76(6), 40-50. DOI: 10.1016/j.technovation.2018.02.013

Malik, A. (2020, September 24). Indonesia akan Resesi? Bareksa. https://www.bareksa.com/ berita/berita-ekonomi-terkini/2020-09-24/

Marpaung, E. \& Sinaga, C. \& Syakur, M. \& Yuniar, A. (2020). Perubahan Paling Signifikan Pemberlakuan PSBB. DOI: 10.13140/RG.2.2.25945.75360.

Marpaung, E. (2020). COVID-19 dan New Normal. https://www.researchgate.net/publication/ 342120384_COVID-19_dan_New_Normal

Muhyiddin, M., \& Nugroho, H.. (2020). Edisi Khusus tentang Covid-19, New Normal, dan Perencanaan Pembangunan. The Indonesian Journal of Development Planning, 4(2), 1-4.

Nicola, M., Alsafi, Z., Sohrabi, C., Kerwan, A., Al-Jabir, A., Iosifidis, C., Agha, M., \& Agha, R. (2020). The Socio-Economic Implications of the Coronavirus and COVID-19 Pandemic: A Review. International Journal of Surgery, 78(5), 185-193. DOI: 10.1016/j.jisu.2020.04.018.

Oplakanskaia, R. V., Osmuk, L. A., \& Pomorina. (2019). Post-industrial university towns and the triple helix concept : case studies of Bristol, Sheffield, Novosibirsk and Tomsk. Bulletin of Geography. Socio-Economic, 44(44), 39-46.

Peraturan Pemerintah Republik Indonesia Nomor 21 Tahun 2020. Pembatasan Sosial Berskala Besar dalam rangka Percepatan Penanganan Corona Virus Disease 2019 (COVID-19). https://jdih.setkab.go.id/PUUdoc/176085/PP_Nomor_21_Tahun_2020.pdf

Rahman, Riska. (2020). COVID-19: Indonesian banks face challenging time but hopes remain. The Jakarta Post. Jakarta/Mon, April 13, 2020/04:32 pm. https://www.thejakartapost.com /news/2020/03/23/indonesias-latest-covid-19-figures.html. Accessed on 14 April 2020.

Sitharam, Sharmilee \& Hoque, Muhammad (2016). Factors affecting the performance of small and medium enterprises in KwaZulu-Natal, South Africa. Problems and Perspectives in Management, 14(2-2), 277-288. DOI: 10.21511/ppm.14(2-2).2016.03.

Surjanti, J., Nuswantara, D. A., Mende, D. R., Juniarti, R. P., \& Musfidah, H. (2018). Developing Triple Helix Model for SMEs with Fish-Based Products. Research and Analysis Journal, 1(2),

Surjanti, J., Soesatyo, Y., \& Wibawa, S. C. (2019). How the Implementation of Science and Technology Transformation in Developing SMEs. Quality Festival2019, 969-978.

Surjanti, J., Soesatyo, Y., Sanaji, S., \& Wibawa, S. C. (2018). Pemahaman UMKM Hijab Gresik Berkearifan Lokal pada Ukuran Keberhasilan. Prosiding Semnas PPM 2018, 1(1), 1950-1961.

Surjanti, J., Soesatyo, Y., Sanaji, \& Wibawa, S. C. (2019). Relationship Between Consumer Response and Science and Technology Implementation at Hijab SMEs in Gresik. Russian Journal of Agricultural and Socio-Economic Sciences, 91(7), 34-41. DOI: 10.18551/rjoas.2019-07.04

Tambunan, T. (2008). SME Development in Indonesia: Do Economic Growth and Government Supports Matter? SSRN Electronic Journal. DOI:10.2139/ssrn.1218922.

Tambunan, T. (2009). Export-oriented small and medium industry clusters in Indonesia. Journal of Enterprising Communities: People and Places in the Global Economy, 3(1), 25-58. DOI:10.1108/17506200910943661.

Taufikurahman, T.; Al Lubbu, Maryam; \& Najmilah, Sarah. (2015). Accompaniment Program for Small Enterprises (SME) Producing Confections made from cilembu sweet potato in Sumedang district, West Java province, Conference Paper,

https://www.researchgate.net/publication/338170055), 07.04 
Hidayati, D., Prasojo, A. P. S., Kusumaningrum, D., Surtiari, G. A. K., \& Aini, Y. N. (2020, June 12). Riset dampak PSBB: meski menerima bantuan pemerintah, warga hanya mampu bertahan seminggu. The Conversation. https://theconversation.com/riset-dampak-psbb-meskimenerima-bantuan-pemerintah-warga-hanya-mampu-bertahan-seminggu-140180

Verlinde, S., Macharis, C. (2016). Innovation in Urban Freight Transport: The Triple Helix Mode. http://doi.org/10.1016/j.technovation.2016.01.002

Gachie, W. (2020) Higher education institutions, private sector and government collaboration for innovation within the framework of the Triple Helix Model. African Journal of Science, Technology, Innovation and Development, 12(2), 203-215. DOI: 10.1080/20421338. 2019.1631120.

WHO. (2020). Coronavirus Disease (COVID-19) Situation Report-115. World Health Organization. https://www.who.int/docs/default-source/coronaviruse/situation-reports/20200514-covid-19sitrep-115.pdf?sfvrsn=3fce8d3c_6.

Widiyani, R. (2020, May 30). Tentang New Normal di Indonesia: Arti, Fakta, dan Kesiapan Daerah. detikNews. https://news.detik.com/berita/d-5034719/tentang-new-normal-di-indonesia-artifakta-dan-kesiapan-daerah.

Yang, C. C. (2003). Improvement actions based on the customers' satisfaction survey. Total Quality Management \& Business Excellence, 14(8), 919-930. DOI: 10.1080/1478336032000090842

Zain, R., Marchand, C., Sun, J., Nguyen, C. H., Bisagni, E., Garestier, T., Hélène, C. (n.d.). Design of a triple-helix-specific cleaving reagent, 771-777.

https://indonesia.go.id/ragam/komoditas/ekonomi/mengenal-konsep-new-norma 